\title{
Transgenesis as a Tool for the Efficient Production of Selected Secondary Metabolites from Plant in Vitro Cultures
}

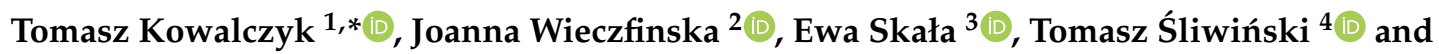 \\ Przemysław Sitarek ${ }^{3}$ \\ 1 Department of Molecular Biotechnology and Genetics, University of Lodz, Banacha 12/16, \\ 90-237 Lodz, Poland \\ 2 Department of Immunopathology, Medical University of Lodz, Żeligowskiego 7/9, 90-752 Lodz, Poland; \\ joanna.wieczfinska@umed.lodz.pl \\ 3 Department of Biology and Pharmaceutical Botany, Medical University of Lodz, Muszynskiego 1, \\ 90-151 Lodz, Poland; ewa.skala@umed.lodz.pl (E.S.); przemyslaw.sitarek@umed.lodz.pl (P.S.) \\ 4 Laboratory of Medical Genetics, University of Lodz, Pomorska 141/143, 90-236 Lodz, Poland; \\ tomasz.sliwinski@biol.uni.lodz.pl \\ * Correspondence: tomasz.kowalczyk@biol.uni.lodz.pl
}

Received: 12 December 2019; Accepted: 19 January 2020; Published: 21 January 2020

\begin{abstract}
The plant kingdom abounds in countless species with potential medical uses. Many of them contain valuable secondary metabolites belonging to different classes and demonstrating anticancer, anti-inflammatory, antioxidant, antimicrobial or antidiabetic properties. Many of these metabolites, e.g., paclitaxel, vinblastine, betulinic acid, chlorogenic acid or ferrulic acid, have potential applications in medicine. Additionally, these compounds have many therapeutic and health-promoting properties. The growing demand for these plant secondary metabolites forces the use of new green biotechnology tools to create new, more productive in vitro transgenic plant cultures. These procedures have yielded many promising results, and transgenic cultures have been found to be safe, efficient and cost-effective sources of valuable secondary metabolites for medicine and industry. This review focuses on the use of various in vitro plant culture systems for the production of secondary metabolites.
\end{abstract}

Keywords: transgenic plants; secondary metabolites; in vitro plant cultures; metabolic engineering; transgenesis; binary vectors

\section{Introduction}

Throughout history, in his struggle with disease, man has continually enlisted help from plants, one of the richer sources of biologically-active health-promoting substances. The oldest evidence of such use was found on a Sumerian clay slab from Nagpur, which is approximately 5000 years old [1]. However, the use of plants in treating ailments is also mentioned in the Pen T'Sao, written by the Emperor of China, Shen Nung, in 2500 BC, the Indian Vedas, the Ebers Papyrus written in 1550 BC, the Bible and the Talmud [2,3]. Almost all medical systems, be they Traditional Medicine, Kampo medicine, Ayurvedic medicine or European medicine, are based on plant-derived valuable medical compounds [4]. Currently, medicine is faced with a growing demand for a wide range of biologically-active compounds of natural origin that can demonstrate preventive or therapeutic effects against primary causes of death, such as cancer, cardiovascular disease, diabetes or respiratory disease. A large proportion of the phytochemicals used for this purpose are secondary metabolites. These compounds are structurally and functionally-diverse products synthesized in plant cells from various primary metabolites, either constitutively or in response to various stimuli. In nature, they 
have many different functions such as protecting plants from pathogens [5,6], ultraviolet light $[7,8]$ or herbivores $[9,10]$, and providing specific fragrances and colors to facilitate pollination and seed distribution by animals. They also play an important role as signaling and regulatory molecules for primary metabolic pathways.

In modern medicine, plant secondary metabolites play a vital role. Since their first isolation in 1803 and the introduction of the alkaloid morphine in 1827 [11], studies have expanded knowledge of their structure, biological function, biosynthesis pathway and possible modifications, thanks to which they can be used to protect human health. Many of their mechanisms of action on various types of normal and cancerous human cells have been described [12-14]. Secondary metabolites can affect cancer cells by interfering with their division, and by changing their metabolism and even the expression of selected genes. Many also have antioxidant [15,16], anti-inflammatory [17,18], antibacterial [19], antifungal [20,21], neurological [22] or hepatoprotective [23] effects. As plants represent such an important source of many secondary metabolites, there is great interest in increasing their biosynthetic rates as part of green biotechnology, which includes the use of transgenic plants or other photosynthetic organisms for industrial purposes. Such approaches allow the production of a wide range of products including secondary metabolites, recombinant proteins, biologically-active compounds, paper and biofuels. They can also be used to improve the nutritional quality of a plant and the development of environmentally-friendly farming solutions.

One of the key strategies enabling the overproduction of valuable plant secondary metabolites in in vitro cultures is the manipulation of existing metabolic pathways by overexpressing or silencing selected elements involved in their biosynthesis [24-27]. A wide range of plant vectors have been designed that allow the simple and quick introduction of synthetic expression cassettes, allowing easier and more effective creation of in vitro transgenic plant cultures [28-30]. Several studies confirm that such modulation of metabolic pathways increases the yield of naturally-occurring biologically-active compounds with potential use in medicine [31-33].

The aim of this work is to review the latest achievements in the transgenesis-based biosynthesis of selected secondary metabolites, particularly anticancer compounds, produced in various types of in vitro plant cultures.

\section{In Vitro Plant Cells and Organ Cultures as an Alternative Source of Secondary Metabolites}

Since the development of the concept of in vitro cell culture in 1902 by the German physiologist Gottlieb Haberlandt, it has been possible to cultivate cells, organs or whole plants of many species under strictly controlled conditions; such approaches employ various biotechnological methods to exploit the totipotency (natural ability to divide and produce differentiated cells) of plant tissue. At present, in vitro plant cultures have been used for agricultural purposes by clonal multiplication of plants [34] and the introduction of novel genetic variations and transgenic plants. They have also found use in pharmaceutical biotechnology, through the production of recombinant proteins, monoclonal antibodies and secondary metabolites, and environmental biotechnology, by developing new methods of eliminating ecological threats and phytoremediation. Plant cell and tissue culture offers many advantages, including the ability to maintain the cells under controlled conditions regardless of changes in environmental conditions, simple extraction of biologically-active compounds, efficient production of many valuable compounds, the ability to easily scale the production process, and faster reproduction of high-quality plant material, especially in the case of slow-growing plants or those producing a small number of seeds. Additionally, this strategy allows pathogen-free material with high levels of the desired biologically-active compounds to be produced. Typically, calli, cell suspension cultures, roots or shoots are most commonly used for obtaining secondary metabolites in vitro. In selected cases, it is necessary to induce cell differentiation in cultures because some metabolites can be synthesized only in specialized plant tissues or glands (e.g., essential oils).

Each of the aforementioned types of in vitro plant cultures has certain characteristic features making it suitable for a chosen group of compounds. All types of cultures have their advantages 
and disadvantages, and care should be taken to select an appropriate type of plant culture to obtain valuable secondary metabolites in the first stage.

\section{From Natural Gene Transfer to Plant Metabolic Engineering}

Over 100 years have passed since the first isolation of Agrobacterium tumefaciens, which later turned out to be a natural genetic engineer of the plant genome [35]. A. tumefaciens is a phytopathogen found in an environment causing neoplastic diseases (crown gall) on various plant species. The bacterium has a natural ability to infect wound sites in plants, resulting in the formation of characteristic tumors [36] by the transfer of T-DNA from the bacterial cell to the plant genome through a bacterial type IV secretion system (T4SS) [37]. The first use of A. tumefaciens infection to obtain transgenic plants was in 1983 [38], which predicted the advent of a new age in plant biotechnology. As the mechanism of transferring genetic material to the plant cell became better understood, such transfection by Agrobacterium has become the most popular method of genetic modification of plants. During transformation, T-DNA is exported from the bacterial cells to the nucleus of the plant cell, where it is integrated into the chromosomal DNA. Interestingly, when infecting plant tissue, Agrobacterium has the ability to inhibit the plant's natural defense response [39].

The molecular mechanism of genetic transformation using Agrobacterium is well understood. It is known that the transfer of genes from a bacterial cell to a plant cell is based on the transfer of T-DNA, which is part of the Ti megaplasmid. This motile genetic element is responsible for tumor induction and biosynthesis of opines in plant tissue. It contains two regions associated with bacterial-plant interactions: vir regions, containing virulence genes $(\operatorname{vir} \mathrm{A}, \operatorname{vir} \mathrm{B}, \operatorname{vir} \mathrm{C}, \operatorname{vir} \mathrm{D}, \operatorname{vir} \mathrm{E}, \operatorname{vir} \mathrm{G}, \operatorname{vir} \mathrm{F}$ and $\operatorname{vir} \mathrm{H})$ encoding proteins actively involved in the transfer and integration of the transgene with the plant genome, and a region containing genes coding the synthesis of inter alia opines, which are used as a source of carbon and nitrogen by bacteria [40]. This procedure allows the creation of transgenic plants by so called stable transformation, in which the new trait is inherited by further generations, or transient transformation, in which the genetic material persists in the cell nucleus without permanent integration with the genetic material. Since the first successful attempts at genetic transformation of plants by Agrobacterium in the early 1980s, the system has demonstrated great potential in transforming dicotyledonous and monocotyledonous plants.

However, other ways exist for changing the plant genome. Such chemical methods include treatment of protoplasts with polyethylene glycol (PEG), facilitating stable and transient transformation [41]. Transformation can also be made more effective by electroporation: the creation of transient micropores in the cell membrane by an electrical impulse to allow the passage of DNA into protoplasts [42]. Finally, microprojectile bombardment can be used, in which particles of gold or tungsten are coated with the appropriately prepared DNA molecules and pushed in the cell by high voltage or compressed gas [43].

Plant genetic transformation has a very wide application in expression of recombinant proteins [44]; these can have many therapeutic or diagnostic uses, increase plant resistance to biotic and abiotic stresses [45] or increase their nutritional or taste values [46]. Another approach is known as metabolic engineering: it can be used to increase the production of selected metabolites that are naturally synthesized in their tissues, or for the synthesis of completely new compounds $[47,48]$.

\section{Binary Vectors as a Basic Tool in Plant Genetic Transformation}

New developments in genetic engineering have allowed much greater control over the transfer of foreign genes to plant cells. A number of vectors can now be used in transgenesis [28,49] that enable different marker and reporter genes and restriction sites to be chosen; they also allow high copy numbers of the binary vectors already in common use in biotechnological laboratories in bacterial cells. Agrobacterium- based transformation typically proceeds according to the following process: first, naturally-occurring oncogenes are removed to deprive the bacterium of pathogenicity; such a strain is often referred to as disarmed. The genes of interest are added to the T-DNA, together with appropriate selection or reporter genes. Due to its large size, the Ti (tumor inducing) or Ri (root 
inducing) plasmid does not replicate in Escherichia coli and hence only occurs in bacterial cells in low copy numbers, thus complicating its isolation; to allow easier manipulation, many works are carried out with a so-called binary vector system. The idea of this approach is to separate vir and T-DNA regions into two independent replicons. The T-DNA is located on a binary vector containing the origin of replication for E.coli and Agrobacterium. This vector also contains left and right borders designating the T-DNA region, selection genes for bacterial and plant cells, and a number of specific sites recognized by restriction enzymes allowing for easy cloning (Figure 1).

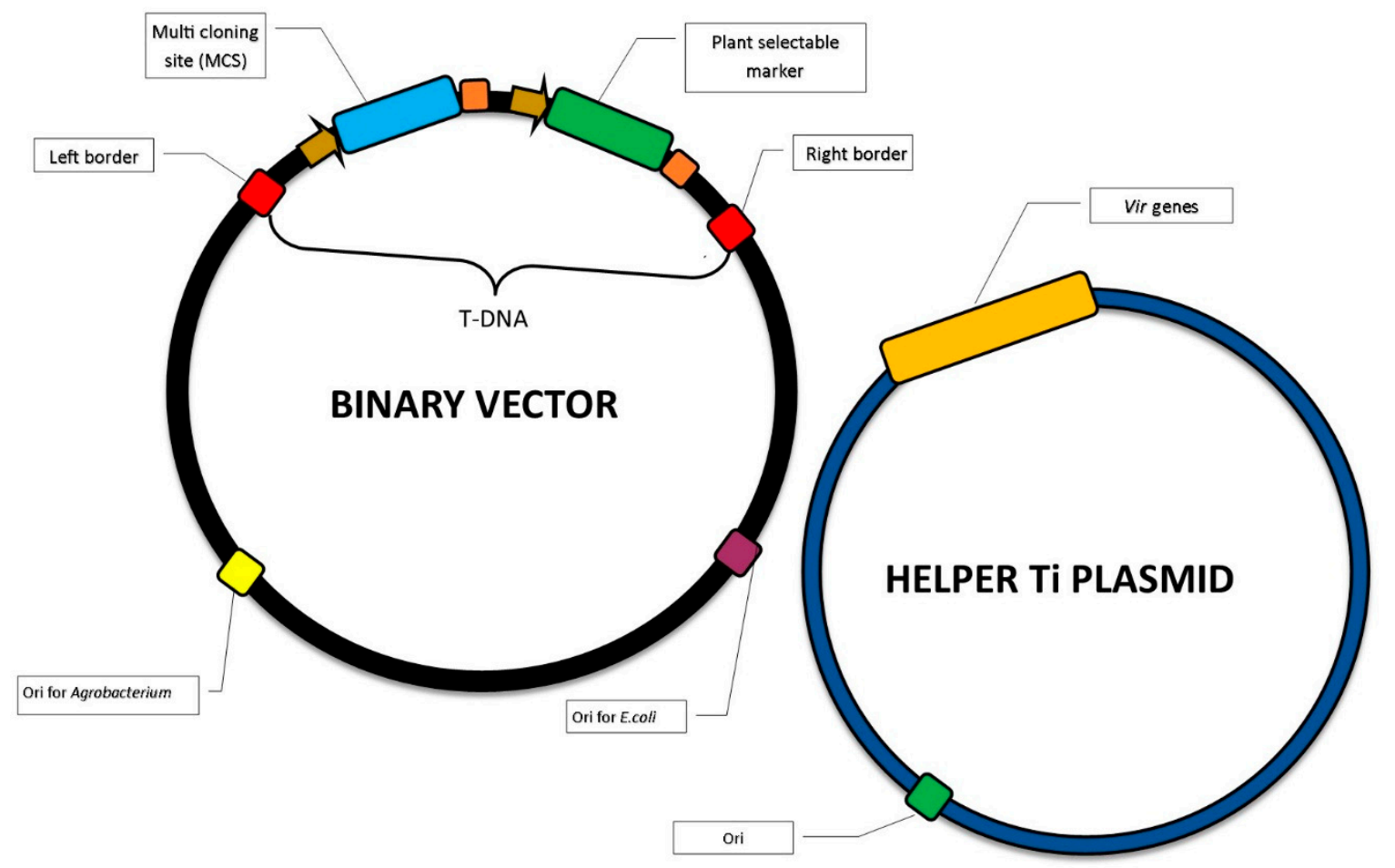

Figure 1. Schematic representation of binary and helper vectors used in plant genetic transformation.

\section{Calli and Cell Suspension Cultures}

Under natural conditions, callus tissue is formed in the plant at the site of its injury from surrounding cells to seal wound sites and prevent water loss [41]. In laboratory conditions, this cell mass is induced on artificial media by using plant growth regulators (mainly auxins and cytokinins). This type of plant culture can be successfully used for the regeneration of whole plants (embryogenic callus) or as a material for establishing plant suspension cultures. One strategy for obtaining selected secondary metabolites involves the use of medicinal plant cell suspension culture (MPCSC), where single cells or different sized aggregates of cells are cultured in agitated liquid medium.

Calli cultures are often used successfully to produce secondary metabolites of medical significance, many of which may be used in treating human diseases [50-53]. The synthesis of the desired compound can be increased by designing the genetic constructs and the way they are introduced. An example would be to induce overexpression of three stilbene synthase (STS) genes of Picea jezoensis (Siebold \& Zucc.) Carr, viz. PjSTS1a, PjSTS2 and PjSTS3, in calli cultures of Vitis amurensis Rupr., resulting in an increase in the content of stilbene [54]. Another example is the overexpression of 1-deoxy-d-xylulose-5-phosphate synthase 1 (SrDXS1) and kaurenoic acid hydroxylase (SrKAH) in Stevia spp., which increases the production of steviol glycosides [55], or the overexpression of stilbene synthase (VaSTS7) to increase production of resveratrol in transgenic cell cultures of $V$. amurensis.

Another good source of secondary metabolites is by the use of transgenic cell suspension cultures. One example is the stable transformation of Silybum marianum (L.) Gaertn. cell suspension cultures with the Vitis vinifera L. stilbene synthase gene, allowing increased accumulation of t-resveratrol [56]. 
In addition, overexpression of the neutral / alkaline invertase (NINV) gene in Taxus chinensis (Rehder \& E.H.Wilson) Rehder cell suspension significantly enhances the expression of the taxadiene synthase (TAS) gene, and the biosynthesis of seven individual taxanes [57].

\section{Hairy Roots}

Hairy root cultures arise as a result of infection of plant tissue by Agrobacterium rhizogenes, resulting in the unlimited growth of organized plant tissue. The ability of these bacteria to infect the plants is due to having large plasmids known as Ri plasmids (root inducing) that contain transfer rol (rolA, rolB, and $\mathrm{rolC}$ ) genes responsible for the stable integration of genetic material into host cells DNA. For many reasons, this system of obtaining valuable biologically active compounds is very convenient. Hairy roots are fast growing, require no plant growth regulators, are highly genetically stable and are able to grow on a large scale [58]. Considering all the advantages of hairy roots over other types of in vitro plant culture systems, they seem to be the best transgenic alternative to medicinal plants occurring in the natural environment. Hairy roots produce relatively large amounts of biologically-active compounds without interference from the natural environment. In addition, the ability to change their metabolic pathways through genetic engineering puts them at the forefront of currently used in vitro plant cultures.

Hairy root cultures have an extremely wide range of applications in green biotechnology [59-61]. As well as production of recombinant proteins, biotransformation or phytoremediation, they are a rich source of many valuable secondary metabolites, especially those produced by medical plants. As a plant production system, hairy roots offer many advantages over bacterial or mammalian systems: they have the ability to synthesize many compounds that are difficult to synthesize chemically, while the ability to grow and develop on simple media makes them attractive for economic reasons. There is no risk of transmission of human or animal pathogens, which is very important for medicinal compounds. So far, many attempts have been made to induce hairy roots with specific traits, most of which are based on genetic engineering techniques that allow plant material with increased utility values to be obtained. A good example of this approach is the heterologous expression of Vitreoscilla hemoglobin in plastids using the $\mathrm{pVHb}-\mathrm{RecA}$ construct, leading to increased production of hyoscyamine and scopolamine in Hyoscyamus niger $\mathrm{L}$. in vitro transgenic plant cultures [62]. Another is the possibility of affecting the increase in the content of glycyrrhizic acid by overexpression of the $\beta$-amyrin synthase gene in hairy roots of Glycyrrhiza uralensis Fisch. ex DC. In this work, a genetic construct containing the tobacco root-specific promoter TobRB7 and GuBAS cDNA was used [63].

\section{Selected Secondary Metabolites in Medical Use Obtained by in Vitro Transgenic Plant Culture}

\subsection{Anticancer Compounds}

Cancer is a serious disease that causes the deaths of many people around the world every year [64] and new therapies are constantly being sought. In this context, compounds of natural origin, including many plant-derived chemicals, including paclitaxel, vinblastine, vincristine and camptothecin, play an extremely important role in prophylaxis and therapy [65-67]. These substances are often safer and less toxic than synthetic ones [68]. Great effort has been invested in increasing their production, and this has resulted in the design of a range of biotechnological methods to increase productivity.

\subsection{Paclitaxel}

Paclitaxel is an anti-cancer drug originally isolated from the bark of the Pacific yew tree, Taxus brevifolia Nutt. in 1971 [69]. It is known to act on microtubules, i.e., the structures responsible for the formation of the mitotic spindle during cell division and cytoplasmic movement in the cell; more specifically, the drug promotes the assembly of microtubules from tubulin dimers and stabilizes microtubules by preventing depolymerization. It thus blocks metaphase-anaphase transitions, inhibits mitosis, and induces apoptosis in a wide range of cancer cells [70]. 
The drug is used in the treatment of a range of conditions including lung, ovarian, breast, stomach, esophageal, cervical, and prostate cancer, as well as lymphoma and leukemia [70]. As this drug is widely used in cancer therapy in humans, there is great interest in increasing its productivity from natural sources. Although paclitaxel can be chemically synthesized [71], this process is not commercially profitable, and its best sources are in vitro and ex vitro plant cultures. A number of previous works have attempted to optimize the process of obtaining taxanes by genetic transformation. Some strategies have resulted in increased paclitaxel production: overexpression of 10-deacetylbaccatin III-10-O-acetyltransferase (DBAT) and taxadiene synthase (TXS) in transgenic Taxus marei (Lemee \& H.Lev.) [72] or TXS in Taxus $\mathrm{x}$ media Rehder var. hicksii cell culture [73]. Other studies have found that enhancement of paclitaxel biosynthesis can be obtained by overexpression of the 9-cis-epoxycarotenoid dioxygenase gene in transgenic cell lines of T. chinensis [70]. In addition, genetic transformation of Nicotiana benthamiana Domin with a taxadiene synthase (TS) gene under control of the 35S Cauliflower Mosaic Virus (CaMV 35S) promoter was found to enable de novo production of taxadiene in $N$. benthamiana homozygous lines, yielding 11-27 $\mu \mathrm{g}$ taxadiene/g of dry weight; in addition, subsequent elicitor treatment (methyl jasmonate) increased taxadiene accumulation by a further 1.4 times [74]. A similar approach based on the in vitro transformation of T. x media hairy roots and subsequent elicitation allowed the production of paclitaxel; the vector was $A$. tumefaciens carrying the RiA4 plasmid and the binary vector pCAMBIA-TXS-His harboring the taxadiene synthase (txs) gene of Taxus baccata L. under the control of the 35S CaMV promoter [75].

\subsection{Camptothecin}

Camptothecin (CPT) is a monoterpene alkaloid and potent inhibitor of topoisomerase I (Top 1): a nuclear enzyme involved in DNA repair, recombination, transcription and replication [76]. This compound and several of its derivatives, such as irinothecan or topothecan, are in clinical use against a number of human cancers. In vitro plant cultures have long been used as a source of camptothecin, with the first works, in which Sakato et al. [77] presented the possibility of acquiring this compound from Camptotheca acuminate Decne cell suspension cultures, dating from the 1970s.

Since these initial studies, more focused attempts have been made to increase camptothecin production using modern biotechnology in plant cells, for example, overexpression of the ORCA3 gene in transgenic hairy root lines [78] and allene oxide cyclase from C. acuminate [79].

Cui et al. [80] obtained Ophiorrhiza pumila Champ. ex Benth hairy roots with separate or simultaneous overexpression of the transformed Catharanthus roseus (L.) G. Don genes for strictosidine synthase $(S T R)$ and geraniol 10-hydroxylase $(\mathrm{G} 10 \mathrm{H})$. Their findings clearly show greater accumulation of CPT in transformed O. pumila hairy roots. Co-overexpression of the G10H and STR genes resulted in a 56\% increase in camptothecin accumulation compared to non-transgenic HR lines. In addition, a comparison of 25 hairy root lines of Ophiorrhiza mungos L., obtained via A. rhizogenes transformation, confirmed elevated camptothecin production in the hairy roots $(0.32 \%$ CPT of DW) compared to non-transformed cultures $(0.25 \%$ CPT of DW) [81]. Wang et al. also reported significantly greater total production of camptothecin in selected transgenic hairy roots of O. pumila. Transformation was performed using a genetic construct encoding tryptophan-arginine-lysine-tyrosine (WRKY), OpWRKY3 isolated from O. pumila, which has high homology with the VvWRKY30 factor [82]. These results further demonstrate the potential of transgenesis to modulate the productivity of plant cells.

\subsection{Vincristine}

Vincristine is one of the first plant alkaloids approved by the FDA for use in the treatment of cancer. In nature, it occurs in the leaves of Catharanthus roseus (L.) G.Don and has been used for a long time in various branches of medicine, including pediatric oncology, as an effective drug against lymphoblastic leukemia [83], rhabdomyosarcoma [84], neuroblastoma [85], Hodgkin lymphoma [86] and Wilms tumor lymphomas [87]. The mechanism of its anti-tumor activity is based on its prevention of microtubule formation by binding to tubulin. As a consequence, mitosis is halted in metaphase 
following disruption of mitotic spindle formation. The compound also has the ability to inhibit the synthesis of nucleic acids and proteins [88].

Canel et al. [89] overexpressed two genes coding for tryptophan decarboxylase and strictosidine synthase in callus and leaf tissue of C. roseus via A. tumefaciens LBA 1119 transformation. Pham et al. [1] also conducted an agrotransformation of periwinkle using a $C r D A T$ transgene encoding deacetylvindoline 4-O-acetyltransferase (DAT): a key enzyme that catalyses the formation of vinblastine and vincristine. The authors demonstrated that selected C. roseus lines are capable of higher accumulation of vincristine through overexpression of the DAT protein, involved in the biosynthesis of terpenoid indole alkaloids (TIAs); in this case, the DAT gene itself was under the control of the CaMV $35 \mathrm{~S}$ promoter. Transformation resulted in 1.63- to 2.48 -fold greater production of vincristine compared to non-transgenic plants. These results show that the expression of DAT can significantly affect the accumulation of vincristine in C. roseus.

\subsection{Vinblastine}

Vinblastine has a similar mechanism of action to vincristine and is also a widely-used plant alkaloid in cancer therapy. Similar to other valuable plant metabolites, vinblastine is also of interest to modern plant biotechnology and many studies have attempted to increase its production in plant tissues. One study examined the effect of overexpression of the MYC1 transcription factor (CrMYC1) in C. roseus [90]. CrMYC1 has been characterized as one of the main components regulating the biosynthesis of terpenoid indole alkaloid metabolites in this plant. Briefly, the authors cloned the CrMYC1 coding sequence into a plant binary vector and then transiently expressed the gene in $C$. roseus by agroinfiltration. The resulting overexpression of this transcription factor increases the level of important terpenoid indole alkaloids such as vinblastine, vincristine or catharantine. The results showed a 2.5-fold increase in vinblastine production and a 3-fold increase in catharanthine relative to control plants. Another study employed transient overexpression of CrERF5 (AP2/ERF transcription factor) in C. roseus petals to increase the expression of key genes in the monoterpene indole alkaloid (MIA) biosynthesis pathways [91]. The transformation led to an increase in the content of the bisindole alkaloids anhydrovinblastine and vinblastine, and the monoindole alkaloids ajmalicine, vindoline and catharanthine.

\section{Overproduction of Other Secondary Metabolites in Transgenic in Vitro Cell Culture}

Each class of secondary metabolites is formed by a complex network of precursors, enzymes and co-factors, some of them leading to specific plant-derived medicinal compounds. In addition to the main anti-cancer alkaloids, which have been presented above, a number of other terpenes, or phenolic compounds, which are common in many other plant species of the Lamiaceae, Asteracea and Fabaceae families, among others, are of potential value. Many such compounds are known to possess various anti-inflammatory, anticancer, antioxidant, antidiabetic, hepatoprotective or antimicrobial properties [15-23]. Of these, the antibacterial properties have drawn significant interest due to the growing problem of bacterial infections around the world [92,93]. These compounds are known to disrupt membrane function and structures, interrupt DNA or RNA synthesis and function, and interfere with intermediary metabolism or intercellular communication via various mechanisms of action $[92,94,95]$. Importantly, the prevalence of multi antibiotic-resistant bacterial strains in the environment is growing [96,97]. A good example of the potential of transformation to improve the biosynthetic efficiency of antibacterial metabolites can be seen in transgenic Codonopsis lanceolata (Siebold \& Zucc.) Beneth. and Hook.f. ex Trautv. over-expressing the $\gamma$-tocopherol methyl transferase $(\gamma$-tmt) gene, which leads to increased antimicrobial activity against gram-positive and gram-negative bacteria compared to controls. The plant was transformed with a genetic construct containing $\gamma$-tmt cDNAs from Arabidopsis thaliana (L.) Heynh. under the control of CaMV 355 promoter and NOS terminator [98]. In turn, Ghimire et al. [99] report that overexpression of the $\gamma$-tmt gene in Perilla frutescens L. increases the levels of phenolic compounds (gallic acid, pyrogallol, 5-sulfosalicylic acid, 
catechin, chlorogenic acid, vanillin, syringic acid, naringenin, salicylic acid, quercetin, $o$-coumaric, kaempferol, hesperetin and benzoic) in the transgenic plants, and that this elevated phenolic content was associated with stronger antimicrobial activity in comparison to wild plants.

Other broad-spectrum metabolites can be modified to increase the production of specific molecules in in vitro plant cultures. For example, over-expression of the AtPAP1 transcriptional factor was found to enhance phenolic acid (such as chlorogenic acid, caffeic acid, ferulic acid or $p$-coumaric acid) production in a transgenic root culture of Leonurus sibiricus L., and the transgenic roots with the AtPAP1 transcriptional factor demonstrated better antimicrobial potential and cytotoxic activity against grade IV glioma cells [100]. Other studies have found such transgenic roots, incorporating the AtPAP1 transcriptional factor, to demonstrate better anticancer effects vis DNA damage, PARP cleavage/increased H2A.X histone levels and UHRF-1/DNMT1 downregulation of mRNA levels compared to untransformed roots [101]. In addition, the extract derived from transgenic L. sibiricus roots overexpressing AtPAP1 demonstrated a stronger cytotoxic effect against melanoma cells and had a higher antioxidant potential in human blood plasma [102]. In turn, better cytotoxic and genotoxic effects were demonstrated against acute lymphoblastic leukemia (CCRF-CEM) and chronic myelogenous leukemia (K562) cell lines after treatment with extract from AtPAP1 transformed roots, possibly due to its higher phenolic acid content [103].

A representative terpene is betulinic acid, a pentacyclic triterpenoid, which is gaining considerable attention due to its unique anti-cancer activity, allowing selective inhibition of melanoma growth without damaging normal cells [104]. Its presence was initially reported in Betula spp., Ocimum spp., Senna spp. and Menynathes spp., among others. Suzuki et al. revealed that metabolic modification of Lotus japonicus L. by changes in CYP716A51 expression may increase betulinic acid biosynthesis [105]. These studies confirm that biotechnology techniques are legitimate tools for increasing the production of secondary metabolites in in vitro plant cultures. Other examples of metabolic pathway manipulation to increase secondary metabolite content in in vitro plant cultures are presented in Table 1 below. 
Table 1. Secondary metabolites derived from genetically-modified plant in vitro cultures with their biological properties.

\begin{tabular}{|c|c|c|c|c|c|c|}
\hline Plant Species & $\begin{array}{l}\text { Vector/Genetic } \\
\text { Construct }\end{array}$ & Plant Material & Extraction Solvent & $\begin{array}{c}\text { Class of } \\
\text { Compounds }\end{array}$ & Effect & References \\
\hline Atropa belladonna L. & $\begin{array}{l}\text { pXI vector containing } \\
\text { NtPMT and HnH6H }\end{array}$ & Whole plant & $\begin{array}{c}\text { methanol and acetate } \\
\text { acetate (methanol:50mM } \\
\text { ammonium acetate }=58: 42)\end{array}$ & Alkaloids & Enhanced biosynthesis of scopolamine & [106] \\
\hline Papaver somniferum L. & $\begin{array}{c}\text { pTRV2-BBE, } \\
\text { pTRV2-COM, } \\
\text { pTRV2-BBECOM } \\
\end{array}$ & Leaves & Methanol & Alkaloids & $\begin{array}{c}\text { Changes in the different alkaloids } \\
\text { content }\end{array}$ & [107] \\
\hline $\begin{array}{l}\text { Arabidopsis thaliana } \\
\text { (L.) Heynh. }\end{array}$ & $\begin{array}{l}\text { pBI121 vector } \\
\text { containing UGT76E11 }\end{array}$ & Seedlings & Methanol & Polyphenols & $\begin{array}{c}\text { increased content of flavonoid } \\
\text { glycosides (kaempferol } \\
\text { 3-O-[6"-O-(rhamnosyl)glucoside] } \\
\text { 7-O-rhamnoside kaempferol } \\
\text { 3-O-glucoside 7-O-rhamnoside, } \\
\text { kaempferol 3-O-rhamnoside } \\
\text { 7-O-rhamnoside quercetin } \\
\text { 3-O-rhamnoside 7-O-rhamnoside and } \\
\text { quercetin 3-O-glucoside } \\
\text { 7-O-rhamnoside) }\end{array}$ & [108] \\
\hline $\begin{array}{l}\text { Arabidopsis thatiana } \\
\text { (L.) Heynh. }\end{array}$ & 35Spro: AtUGT78D1 & Seedlings & Methanol & Polyphenols & Increased accumulation of flavonoids & [109] \\
\hline $\begin{array}{l}\text { Arabidopsis thatiana } \\
\text { (L.) Heynh. }\end{array}$ & pCAMBIA1301-AtMYB12 & Seedlings & HCl-methanol & Polyphenols & Increased content of flavonoids & [110] \\
\hline $\begin{array}{l}\text { Arabidopsis thaliana } \\
\text { (L.) Heynh. }\end{array}$ & $\begin{array}{l}\text { pCAMBIA1301- } \\
\text { AeCHS }\end{array}$ & Seedlings & HCl-methanol & Polyphenols & Increased level of flavonoids & [111] \\
\hline $\begin{array}{l}\text { Arabidopsis thaliana } \\
\text { (L.) Heynh. }\end{array}$ & pCAMBIA1301-AmDEL & Seedlings & HCl-methanol & Polyphenols & Increased level of flavonoids & [112] \\
\hline $\begin{array}{l}\text { Ipomoea batatas } \\
\text { (L. Poir.) }\end{array}$ & pCam-SPO-IbMYB1a & Storage root & Methanol & Polyphenols & Increased anthocyanin content & [113] \\
\hline $\begin{array}{l}\text { Ipomoea batatas } \\
\text { (L. Poir.) }\end{array}$ & $\begin{array}{l}\text { pGWB11 vector } \\
\text { containing IbOr }\end{array}$ & Storage root & HCl-methanol & Polyphenols & $\begin{array}{l}\text { Enhanced accumulation of zeaxanthin } \\
\text { and } \beta \text {-carotene }\end{array}$ & [114] \\
\hline Leonurus sibiricus L. & pCAMBIA1305.1-AtPAP1 & Hairy roots & Methanol-water & Polyphenols & $\begin{array}{l}\text { Higher phenolic acid content. In } \\
\text { addition, tested extracts with higher } \\
\text { amounts of phenolic acids showed better } \\
\text { antimicrobial and cytotoxic effect. }\end{array}$ & [102] \\
\hline Linum usitatissimum $\mathrm{L}$. & pBinAR & Whole plants & HCl-methanol & Polyphenols & Increased level of flavonoids & [115] \\
\hline
\end{tabular}


Table 1. Cont

\begin{tabular}{|c|c|c|c|c|c|c|}
\hline Plant Species & $\begin{array}{l}\text { Vector/Genetic } \\
\text { Construct }\end{array}$ & Plant Material & Extraction Solvent & $\begin{array}{c}\text { Class of } \\
\text { Compounds }\end{array}$ & Effect & References \\
\hline $\begin{array}{l}\text { Nicotiana benthamiana } \\
\text { Domin }\end{array}$ & pMV-EsMYBF1 & Flowers & HCl-methanol & Polyphenols & Increased production of flavonol content & [116] \\
\hline Nicotiana tabacum L. & $\begin{array}{l}\text { pGR-STS and } \\
\text { pGR-ROST }\end{array}$ & Whole plant & $80 \%$ metanol & Polyphenols & $\begin{array}{l}\text { Increased production of resveratrol } \\
\text { derivatives (piceid, piceid methyl ether, } \\
\text { resveratrol methyl ether O-hexoside, } \\
\text { and 5-methyl resveratrol-3,4-O- } \beta \text { - } \\
\text { d-diglucopyranoside) }\end{array}$ & [117] \\
\hline Nicotiana tabacum $\mathrm{L}$. & $\begin{array}{l}\text { pK2GW7 vector } \\
\text { containing NtFLS2 }\end{array}$ & Leaves & $\begin{array}{c}\text { Methanol-water-chloroform } \\
(5: 2: 2)\end{array}$ & Polyphenols & Increased accumulation of rutin & [118] \\
\hline Nicotiana tabacum $\mathrm{L}$. & $\begin{array}{c}\text { pCambia1305 } \\
\text { containing SbMYB8 }\end{array}$ & Leaves & Ethyl alcohol & Polyphenols & higher caffeoylquinic acid contents & [119] \\
\hline Nicotiana tabacum L. & $\begin{array}{l}\text { pZIP-Bar containing } \\
\text { PgDDS, CYP716A47 } \\
\text { and UGT71A28 }\end{array}$ & Leaves & $100 \%$ methanol & Polyphenols & $\begin{array}{c}\text { Enhanced production of ginsenoside } \\
\text { saponin }\end{array}$ & [120] \\
\hline Nicotiana tabacum L. & $\begin{array}{l}\text { pSAK277 vector } \\
\text { containing } \\
\text { 35S:StMYBA1-1 } \\
\text { construct } \\
\end{array}$ & Leaves & HCl-methanol & Polyphenols & Enhanced anthocyanin accumulation & [121] \\
\hline $\begin{array}{l}\text { Petunia } \times \text { hybrida hort. } \\
\text { ex E.Vilm }\end{array}$ & $\begin{array}{l}\text { pBI-121 containing } \\
\text { Fh3GT1 }\end{array}$ & Blooming flowers & HCl-methanol & Polyphenols & $\begin{array}{l}\text { Increased production of cyaniding, } \\
\text { peonidin derivatives, kaempferol } \\
\text { derivatives and quercetin derivatives }\end{array}$ & [122] \\
\hline $\begin{array}{l}\text { Petunia } \times \text { hybrida hort. } \\
\text { ex E.Vilm }\end{array}$ & $\begin{array}{l}\text { pB7WG2D vector } \\
\text { containing RsMYB1 }\end{array}$ & Leaves & HCl-methanol & Polyphenols & Enhanced accumulation of flavonoids & [123] \\
\hline $\begin{array}{l}\text { Salvia miltiorrhiza } \\
\text { Bunge }\end{array}$ & $\begin{array}{l}\text { pCAMBIA2300 vector } \\
\text { containing SmANS }\end{array}$ & Plantlets & HCl-methanol & Polyphenols & $\begin{array}{c}\text { Increased anthocyanin accumulation, } \\
\text { flavonols and proanthocyanidins } \\
\text { biosynthesis }\end{array}$ & [124] \\
\hline $\begin{array}{l}\text { Salvia miltiorrhiza } \\
\text { Bunge }\end{array}$ & pCB2006-EDT1 & Roots & $80 \%$ methanol & Polyphenols & $\begin{array}{l}\text { Increased accumulation of salvianolic } \\
\text { acids }\end{array}$ & [125] \\
\hline $\begin{array}{l}\text { Salvia miltiorrhiza } \\
\text { Bunge }\end{array}$ & pEarleyGate201-SmMYC2 & Roots & $75 \%$ methanol & Polyphenols & $\begin{array}{l}\text { Enhanced production of hydrophilic } \\
\text { phenolic acids }\end{array}$ & [126] \\
\hline $\begin{array}{l}\text { Salvia miltiorrhiza } \\
\text { Bunge }\end{array}$ & pEarleyGate202-SmJMT & Roots & Methanol-acetone (7:3) & Polyphenols & $\begin{array}{l}\text { Increased production of salvianolic and } \\
\text { rosmarinic acids }\end{array}$ & [127] \\
\hline
\end{tabular}


Table 1. Cont

\begin{tabular}{|c|c|c|c|c|c|c|}
\hline Plant Species & $\begin{array}{l}\text { Vector/Genetic } \\
\text { Construct }\end{array}$ & Plant Material & Extraction Solvent & $\begin{array}{l}\text { Class of } \\
\text { Compounds }\end{array}$ & Effect & References \\
\hline $\begin{array}{l}\text { Solanum lycopersicum } \\
\text { L. }\end{array}$ & $\begin{array}{l}\text { pE1775-CHI } \\
\text { pDEL.ROS }\end{array}$ & Flesh and peel & HCl-methanol & Polyphenols & Enhanced anthocyanins and flavonols & [128] \\
\hline $\begin{array}{l}\text { Solanum lycopersicum } \\
\text { L. }\end{array}$ & $\begin{array}{c}\text { K303 vector } \\
\text { containing SIMYB75 }\end{array}$ & Fruits & $80 \%$ methanol & Polyphenols & $\begin{array}{l}\text { Increased accumulation of anthocyanin, } \\
\text { phenolics and flavonoids }\end{array}$ & [129] \\
\hline Solanum melongena $\mathrm{L}$. & $\begin{array}{l}\text { pBIN19+SmHQT } \\
\text { pBIN19+p19 }\end{array}$ & Fruits & Methanol-water (80:20) & Polyphenols & Increased level of phenolic compounds & [130] \\
\hline $\begin{array}{c}\text { Taraxacum } \\
\text { brevicorniculatum } \\
\text { Korol. }\end{array}$ & pBI-AtPAP1 & Leaves & Methanol and formic acid & Polyphenols & $\begin{array}{l}\text { Increased production of anthocyanins, } \\
\text { phenolic acids and flavonoids }\end{array}$ & [131] \\
\hline $\begin{array}{l}\text { Trachyspermum ammi } \\
\text { L. Sprague }\end{array}$ & pBI121-TP & Leaves & $80 \%$ ethanol & Polyphenols & Increased production of thymol & [132] \\
\hline Withania somnifera $\mathrm{L}$. & $\begin{array}{c}\text { pYL436 vector } \\
\text { containing Ws-Sgt14 }\end{array}$ & Hairy roots & Methanol & Steroids & $\begin{array}{l}\text { Increased withanolide and } \\
\text { withanolide-A contents }\end{array}$ & [133] \\
\hline Artemisia annua L. & pCAMBIA1305-DBR2 & Leaves & Methanol & Terpenoids & Increased level of artemisinin & [134] \\
\hline Artemisia aппиа $L$. & pIG-TfGA20ox2 & Leaves & Methanol & Terpenoids & $\begin{array}{l}\text { Increased production of artemisinin, } \\
\text { sesquiterpenes. Eucalyptol, borneol, } \\
\alpha \text {-caryophyllene, } \beta \text {-guaiene, } \delta \text {-cadinene } \\
\text { and } \beta \text {-cubebene and isomultiflorenone } \\
\text { were detected only in transgenic extract }\end{array}$ & [135] \\
\hline Betula platyphylla & pSGRNAi-GSNOR & $\begin{array}{l}\text { Cell suspension or } \\
\text { plantlet stems }\end{array}$ & Ethanol & Triterpenoids & Increased betulin content & [136] \\
\hline Citrus grandis L. & pK2- CsMADS6 & Calli and fruit & - & Terpenoids & increased carotenoid contents & [137] \\
\hline $\begin{array}{l}\text { Lavandula latifolia } \\
\text { Medik. }\end{array}$ & pBILIS & Leaves & Hexane & Triterpenoids & $\begin{array}{l}\text { Increased production of terpenes } \\
\text { (S-linalool) }\end{array}$ & [138] \\
\hline Mentha spicata L. & $\begin{array}{l}\text { pK7WG2D- } \\
\text { MsYABBY5 }\end{array}$ & Leaves & Ethyl acetate & Triterpenoids & $\begin{array}{l}\text { Increased production of terpenes by } \\
\text { gene silencing }\end{array}$ & [139] \\
\hline Mentha spicata $L$. & $\begin{array}{l}\text { pB1121 vector } \\
\text { containing IPP }\end{array}$ & Whole plants & - & Terpenoids & Increased production of terpenoids & [140] \\
\hline Nicotiana tabacum L. & pSKAN35SGES & Leaves & Methanol & Triterpenoids & Increased production of terpenes & [141] \\
\hline $\begin{array}{l}\text { Panax ginseng CA } \\
\text { Meyer }\end{array}$ & $\begin{array}{l}\text { pCAMBIA1390 vector } \\
\text { containing PgLOX6 }\end{array}$ & Roots & $80 \%$ methanol & Terpenoids & Increased production of ginsenosides & [142] \\
\hline
\end{tabular}


Table 1. Cont.

\begin{tabular}{|c|c|c|c|c|c|c|}
\hline Plant Species & $\begin{array}{l}\text { Vector/Genetic } \\
\text { Construct }\end{array}$ & Plant Material & Extraction Solvent & $\begin{array}{l}\text { Class of } \\
\text { Compounds }\end{array}$ & Effect & References \\
\hline $\begin{array}{l}\text { Pelargonium graveolens } \\
\text { L'Her and Withania } \\
\text { somnifera (L.) Dunal }\end{array}$ & $\begin{array}{l}\text { pBI121 vector } \\
\text { containing } \\
\text { GrDXS }\end{array}$ & Whole plants & - & Terpenoids & $\begin{array}{l}\text { Increased production of essential oil and } \\
\text { withanolides }\end{array}$ & [143] \\
\hline $\begin{array}{l}\text { Salvia miltiorrhiza } \\
\text { Bunge }\end{array}$ & $\begin{array}{l}\text { pBI121 vector } \\
\text { containing SmMDS }\end{array}$ & Hairy roots & $80 \%$ methanol & Terpenoids & $\begin{array}{l}\text { increased accumulation of tanshinones } \\
\text { (dihydrotanshinone I, cryptotanshinone, } \\
\text { tanshinone I andtanshinone IIA) }\end{array}$ & [144] \\
\hline $\begin{array}{l}\text { Salvia miltiorrhiza } \\
\text { Bunge }\end{array}$ & pCAMBIA2300sm-SmWRK) & Y2 Hairy roots & $\begin{array}{c}\text { Methanol/di- } \\
\text { chloromethane (3:1) }\end{array}$ & Terpenoids & Increased accumulation of tanshinones & [145] \\
\hline Salvia sclarea L. & $\begin{array}{l}\text { PKYLX71:35S vector } \\
\text { containing DXS or } \\
\text { DXR }\end{array}$ & Hairy roots & Acetone & Terpenoids & $\begin{array}{c}\text { Enhanced biosynthesis of abietane } \\
\text { diterpenes }\end{array}$ & [146] \\
\hline Brassica rapa $\mathrm{L}$. & $\begin{array}{l}\text { pBI121S vector } \\
\text { containing BraLTP2 }\end{array}$ & Leaves & Methanol-water & $\begin{array}{l}\text { Different } \\
\text { metabolites }\end{array}$ & $\begin{array}{l}\text { Upregulation of } 43 \text { different secondary } \\
\text { metabolites. }\end{array}$ & [147] \\
\hline $\begin{array}{l}\text { Lycium ruthenicum } \\
\text { Murr. }\end{array}$ & pCAMBIA1307-TCP4-OE & Hairy roots & Methanol & $\begin{array}{c}\text { Different } \\
\text { metabolites }\end{array}$ & $\begin{array}{l}\text { higher relative abundances of different } \\
\text { secondary metabolites }\end{array}$ & [148] \\
\hline
\end{tabular}




\section{In Vitro Transgenic Plant Cultures and Societal Implication}

The intensive pace of recent scientific progress has been accompanied by a similar growth in public interest regarding issues related to health protection and the treatment of civilization diseases. In addition, with the growth in awareness of the dangers associated with a polluted environment, and the measurable economic benefits associated with productive agriculture, comes a greater willingness to accept research on genetic modification. With this in mind, the metabolic engineering of plant cells is an effective way to obtain valuable biologically-active compounds for pharmaceuticals. Today, thanks to modern biotechnology, it is possible to produce many therapeutics, even on an industrial scale.

Plant-based genetic manipulation is regarded as far more acceptable than such work with animals. Humans have modified plant genomes using conventional methods (crossing) for thousands of years. In addition, as the use of in vitro transgenic plant cultures is usually limited only to the laboratory, they do not have such negative connotations as the production of transgenic crops. In addition, given the appropriate cooperation of the scientific community, such research enjoys quite high social acceptance. Most importantly, green biotechnology can significantly contribute to achieving many of the sustainable development goals (SDGs) set in 2015 by the United Nations, these being intended to cover a broad range of global social and economic development targets by 2030 [149].

\section{Conclusions}

Many compounds currently used in medicine are of plant origin, and the literature suggests a growing tendency to return to biologically-active compounds of natural origin. In contrast to chemically synthesized compounds, many compounds from a natural origin show greater biological safety, generate fewer side effects and are often characterized by lower production costs. However, due to their limited adaptability, the diversity of medicinal plant species in their natural environment has been shrinking the face of intense and unfavorable climate change and growing anthropogenic environmental pollution. In response to this, and the constantly growing demand for compounds of plant origin, new and more efficient in vitro techniques for growing plants are being developed. The literature reviewed showed that in combination with the currently-available precision tools of molecular biology and genetic engineering, high-throughput in vitro plant cultures can be in some cases used to provide many natural secondary metabolites. Modern green biotechnology, which allows manipulation of cellular processes at many levels, can be an excellent alternative to traditional methods of obtaining biologically-active compounds. The ability to create various genetic constructs and introduce them into the plant genome can be an efficient production platform for a wide range of compounds used in medicine, diagnostics or industry. Currently, intensive work is underway on new biotechnological solutions and sustainable alternative methods of producing high-value plant metabolites.

Author Contributions: Conceptualization: T.K.; T.K. wrote the manuscript with support from P.S. and J.W., critical review: E.S. and T.Ś. All authors have read and agreed to the published version of the manuscript.

Funding: This research received no external funding.

Conflicts of Interest: The authors declare no conflict of interest.

\section{References}

1. Pham, T.T.N.; Nguyen, T.N.L.; Bui, T.H.; Nguyen, H.Q.; Nguyen, T.T.; Le, V.S.; Chu, H.M. Agrobacteriummediated transformation of the $C r D A T$ gene and selection of transgenic periwinkle lines with a high vincristine accumulation. J. Hortic. Sci. Biotechnol. 2019, 94, 591-598. [CrossRef]

2. Petrovska, B.B. Historical review of medicinal plants' usage. Pharmacogn. Rev. 2012, 6, 1-5. [CrossRef] [PubMed]

3. Kumar, A.; Kumar, S.; Thomas, T.D.; Ramchiary, N.; Swamy, M.K.; Ahmad, I. Linking Omics Approaches to Medicinal Plants and Human Health. In Natural Bio-Active Compounds; Springer: Berlin/Heidelberg, Germany, 2019; pp. 31-57. 
4. Lu, X.; Tang, K.; Li, P. Plant metabolic engineering strategies for the production of pharmaceutical terpenoids. Front. Plant Sci. 2016, 7, 1-11. [CrossRef] [PubMed]

5. Zaynab, M.; Fatima, M.; Abbas, S.; Sharif, Y.; Umair, M.; Zafar, M.H.; Bahadar, K. Role of secondary metabolites in plant defense against pathogens. Microb. Pathog. 2018, 124, 198-202. [CrossRef]

6. Bednarek, P.; Schulze-Lefert, P. Role of Plant Secondary Metabolites at the Host-Pathogen Interface. In Molecular Aspects of Plant Disease Resistance 2018; Parker, J., Ed.; Wiley-Blackwell: Hoboken, NJ, USA, 2008; Volume 34, pp. 220-260.

7. Köhler, H.; Contreras, R.A.; Pizarro, M.; Cortés-Antíquera, R.; Zúñiga, G.E. Antioxidant responses induced by UVB radiation in Deschampsia Antarctica Desv. Front. Plant Sci. 2017, 8, 1-10. [CrossRef]

8. Takshak, S.; Agrawal, S.B. Defense potential of secondary metabolites in medicinal plants under UV-B stress. J. Photochem. Photobiol. B Biol. 2019, 193, 51-88. [CrossRef]

9. Huang, W.; Gfeller, V.; Erb, M. Root volatiles in plant-plant interactions II: Root volatiles alter root chemistry and plant-herbivore interactions of neighbouring plants. Plant Cell Environ. 2019, 42, 1964-1973. [CrossRef]

10. Huber, M.; Epping, J.; Schulze Gronover, C.; Fricke, J.; Aziz, Z.; Brillatz, T.; Swyers, M.; Köllner, T.G.; Vogel, H.; Hammerbacher, A.; et al. A Latex Metabolite Benefits Plant Fitness under Root Herbivore Attack. PLoS Biol. 2016, 14, 1-27. [CrossRef]

11. Miró, Ò.; Gil, V.; Peacock, W.F. Morphine in acute heart failure: Good in relieving symptoms, bad in improving outcomes. J. Thorac. Dis. 2017, 9, E871-E874. [CrossRef]

12. Holan, V.; Cechova, K.; Zajicova, A.; Kossl, J.; Hermankova, B.; Bohacova, P.; Hajkova, M.; Krulova, M.; Svoboda, P.; Javorkova, E. The Impact of Morphine on the Characteristics and Function Properties of Human Mesenchymal Stem Cells. Stem Cell Rev. Rep. 2018, 14, 801-811. [CrossRef]

13. Tuerxun, H.; Cui, J. The dual effect of morphine on tumor development. Clin. Transl. Oncol. 2019, 21, 695-701. [CrossRef]

14. Nishiwada, T.; Kawaraguchi, Y.; Uemura, K.; Kawaguchi, M. Morphine inhibits cell viability and growth via suppression of vascular endothelial growth factor in human oral cancer HSC-3 cells. J. Anesth. 2019, 33, 408-415. [CrossRef] [PubMed]

15. Zlatić, N.; Jakovljević, D.; Stanković, M. Temporal, plant part, and interpopulation variability of secondary metabolites and antioxidant activity of Inula helenium L. Plants 2019, 8, 179. [CrossRef]

16. Gonçalves, S.; Mansinhos, I.; Rodríguez-Solana, R.; Pérez-Santín, E.; Coelho, N.; Romano, A. Elicitation improves rosmarinic acid content and antioxidant activity in Thymus lotocephalus shoot cultures. Ind. Crops Prod. 2019, 137, 214-220. [CrossRef]

17. Bernstein, N.; Akram, M.; Daniyal, M.; Koltai, H.; Fridlender, M.; Gorelick, J. Antiinflammatory Potential of Medicinal Plants: A Source for Therapeutic Secondary Metabolites, 1st ed.; Elsevier Inc.: Amsterdam, The Netherlands, 2018; Volume 150.

18. Flores-Sánchez, K.; Cruz-Sosa, F.; Zamilpa-Alvarez, A.; Nicasio-Torres, P. Active compounds and anti-inflammatory activity of the methanolic extracts of the leaves and callus from Tilia americana var. mexicana propagated plants. Plant Cell Tissue Organ Cult. 2019, 137, 55-64. [CrossRef]

19. Barbieri, R.; Coppo, E.; Marchese, A.; Daglia, M.; Sobarzo-Sánchez, E.; Nabavi, S.F.; Nabavi, S.M. Phytochemicals for human disease: An update on plant-derived compounds antibacterial activity. Microbiol. Res. 2017, 196, 44-68. [CrossRef]

20. Reichling, J. Plant-Microbe Interactions and Secondary Metabolites with Antibacterial, Antifungal and Antiviral Properties, 2nd ed.; Functions and Biotechnology of Plant Secondary Metabolites, Chapter 4; Annual Plant Reviews; Wink, M., Ed.; Wiley: Oxford, UK, 2010; Volume 39.

21. Lagrouh, F.; Dakka, N.; Bakri, Y. The antifungal activity of Moroccan plants and the mechanism of action of secondary metabolites from plants. Journal de Mycologie Medicale 2017, 27, 303-311. [CrossRef] [PubMed]

22. Epifano, F.; Molinaro, G.; Genovese, S.; Ngomba, R.T.; Nicoletti, F.; Curini, M. Neuroprotective effect of prenyloxycoumarins from edible vegetables. Neurosci. Lett. 2008, 443, 57-60. [CrossRef] [PubMed]

23. Pereira, C.; Barros, L.; Ferreira, I.C. Extraction, identification, fractionation and isolation of phenolic compounds in plants with hepatoprotective effects. J. Sci. Food Agric. 2016, 96, 1068-1084. [CrossRef]

24. Zhou, M.; Memelink, J. Jasmonate-responsive transcription factors regulating plant secondary metabolism. Biotechnol. Adv. 2016, 34, 441-449. [CrossRef]

25. Nielsen, E.; Temporiti, M.E.E.; Cella, R. Improvement of phytochemical production by plant cells and organ culture and by genetic engineering. Plant Cell Rep. 2019, 38, 1199-1215. [CrossRef] [PubMed] 
26. Sui, X.; Zhao, M.; Xu, Z.; Zhao, L.; Han, X. RrGT2, a key gene associated with anthocyanin biosynthesis in Rosa rugosa, was identified via virus-induced gene silencing and overexpression. Int. J. Mol. Sci. 2018, 19, 4057. [CrossRef] [PubMed]

27. Catania, T.M.; Branigan, C.A.; Stawniak, N.; Hodson, J.; Harvey, D.; Larson, T.R.; Czechowski, T.; Graham, I.A. Silencing amorpha-4,11-diene synthase genes in Artemisia annua leads to FPP accumulation. Front. Plant Sci. 2018, 9, 1-12. [CrossRef]

28. Bahramnejad, B.; Naji, M.; Bose, R.; Jha, S. A critical review on use of Agrobacterium rhizogenes and their associated binary vectors for plant transformation. Biotechnol. Adv. 2019, 1-14. [CrossRef] [PubMed]

29. Lampropoulos, A.; Sutikovic, Z.; Wenzl, C.; Maegele, I.; Lohmann, J.U.; Forner, J. GreenGate-A novel, versatile, and efficient cloning system for plant transgenesis. PLoS ONE 2013, 8, e83043. [CrossRef] [PubMed]

30. Dafny-Yelin, M.; Tzfira, T. Delivery of multiple transgenes to plant cells. Plant Physiol. 2007, 145, 1118-1128. [CrossRef]

31. Ncube, B.; van Staden, J. Tilting plant metabolism for improved metabolite biosynthesis and enhanced human benefit. Molecules 2015, 20, 12698-12731. [CrossRef]

32. Guerriero, G.; Berni, R.; Muñoz-Sanchez, J.A.; Apone, F.; Abdel-Salam, E.M.; Qahtan, A.A.; Alatar, A.A.; Cantini, C.; Cai, G.; Hausman, J.F.; et al. Production of plant secondary metabolites: Examples, tips and suggestions for biotechnologists. Genes 2018, 9, 309. [CrossRef]

33. Shi, M.; Luo, X.; Ju, G.; Li, L.; Huang, S.; Zhang, T.; Wang, H.; Kai, G. Enhanced Diterpene Tanshinone Accumulation and Bioactivity of Transgenic Salvia miltiorrhiza Hairy Roots by Pathway Engineering. J. Agric. Food Chem. 2016, 64, 2523-2530. [CrossRef]

34. Hemanthakumar, A.S.; Preetha, T.S.; Pillai, P.P.; Seeni, S. Embryogenesis followed by enhanced micro-multiplication and eco-restoration of Calamus thwaitesii Becc.: An economic non-wood forest produce for strengthening agroforestry system. Agrofor. Syst. 2019, 93, 1093-1105. [CrossRef]

35. Kado, C.I. Historical account on gaining insights on the mechanism of crown gall tumorigenesis induced by Agrobacterium tumefaciens. Front. Microbiol. 2014, 5, 1-15. [CrossRef] [PubMed]

36. Nester, E.W. Agrobacterium: Nature's Genetic Engineer. Front. Plant Sci. 2015, 5, 1-16. [CrossRef] [PubMed]

37. Aguilar, J.; Zupan, J.; Cameron, T.A.; Zambryski, P.C. Agrobacterium type IV secretion system and its substrates form helical arrays around the circumference of virulence-induced cells. Proc. Natl. Acad. Sci. USA 2010, 107, 3758-3763. [CrossRef] [PubMed]

38. Bevan, M.W.; Flavell, R.B.; Chilton, M.D. A chimaeric antibiotic resistance gene as a selectable marker for plant cell transformation. Nature 1983, 304, 184-187. [CrossRef]

39. Pitzschke, A. Agrobacterium infection and plant defense-transformation success hangs by a thread. Front. Plant Sci. 2013, 4, 1-12. [CrossRef]

40. Guo, M.; Ye, J.; Gao, D.; Xu, N.; Yang, J. Agrobacterium-mediated horizontal gene transfer: Mechanism, biotechnological application, potential risk and forestalling strategy. Biotechnol. Adv. 2019, 37, 259-270. [CrossRef]

41. Ikeuchi, M.; Iwase, A.; Rymen, B.; Lambolez, A.; Kojima, M.; Takebayashi, Y.; Heyman, J.; Watanabe, S.; Seo, M.; de Veylder, L.; et al. Wounding triggers callus formation via dynamic hormonal and transcriptional changes. Plant Physiol. 2017, 175, 1158-1174. [CrossRef]

42. Chen, L.; Masuoka, S.; Nishimura, Y.; Sakai, T.; Takahata, Y.; Xu, C. Attempt to Establish Direct Gene Transformation System to Seeds of Sweet Potato (Ipomoea batatas) Using Electroporation Method. Biotechnol. J. Int. 2017, 19, 1-8. [CrossRef]

43. Gao, S.; Yang, Y.; Xu, L.; Guo, J.; Su, Y.; Wu, Q.; Wang, C.; Que, Y. Particle bombardment of the cry2A gene cassette induces stem borer resistance in sugarcane. Int. J. Mol. Sci. 2018, 19, 1692. [CrossRef]

44. Buyel, J.F. Plants as sources of natural and recombinant anti-cancer agents. Biotechnol. Adv. 2018, 36, 506-520. [CrossRef]

45. Erpen, L.; Devi, H.S.; Grosser, J.W.; Dutt, M. Potential use of the DREB/ERF, MYB, NAC and WRKY transcription factors to improve abiotic and biotic stress in transgenic plants. Plant Cell Tissue Organ Cult. 2018, 132, 1-25. [CrossRef]

46. Reddy, C.S.; Vijayalakshmi, M.; Kaul, T.; Islam, T.; Reddy, M.K. Improving Flavour and Quality of Tomatoes by Expression of Synthetic Gene Encoding Sweet Protein Monellin. Mol. Biotechnol. 2015, 57, 448-453. [CrossRef] [PubMed] 
47. Satish, L.; Rency, A.S.; Muthubharathi, B.C.; Shamili, S.; Rameshkumar, R.; Swamy, M.K.; Ramesh, M. Transgenic Plant Cell Cultures: A Promising Approach for Secondary Metabolite Production. In Natural Bio-Active Compounds; Akhtar, M., Swamy, M., Eds.; Springer: Singapore, 2019.

48. Jensen, P.E.; Scharff, L.B. Engineering of plastids to optimize the production of high-value metabolites and proteins. Curr. Opin. Biotechnol. 2019, 59, 8-15. [CrossRef]

49. Pasin, F.; Bedoya, L.C.; Bernabé-Orts, J.M.; Gallo, A.; Simón-Mateo, C.; Orzaez, D.; García, J.A. Multiple T-DNA Delivery to Plants Using Novel Mini Binary Vectors with Compatible Replication Origins. ACS Synth. Biol. 2017, 6, 1962-1968. [CrossRef]

50. Deshpande, A.; Dhadi, S.R.; Hager, E.J.; Ramakrishna, W. Anticancer activity of rice callus suspension culture. Phytother. Res. 2012, 26, 1075-1081. [CrossRef]

51. Mittal, J.; Sharma, M.M. Enhanced production of berberine in In vitro regenerated cell of Tinospora cordifolia and its analysis through LCMS QToF. 3 Biotech 2017, 7, 1-12. [CrossRef]

52. Rady, M.R.; Aboul-Enein, A.M.; Ibrahim, M.M. Active compounds and biological activity of in vitro cultures of some Echinacea purpurea varieties. Bull. Nat. Res. Cent. 2018, 42, 1-12. [CrossRef]

53. Rahpeyma, S.A.; Moieni, A.; Jalali Javaran, M. Paclitaxel production is enhanced in suspension-cultured hazel (Corylus avellana L.) cells by using a combination of sugar, precursor, and elicitor. Eng. Life Sci. 2015, 15, 234-242. [CrossRef]

54. Suprun, A.R.; Ogneva, Z.V.; Dubrovina, A.S.; Kiselev, K.V. Effect of spruce PjSTS1a, PjSTS2, or PjSTS3 gene overexpression on stilbene biosynthesis in callus cultures of Vitis amurensis Rupr. Biotechnol. Appl. Biochem. 2019, 1-7. [CrossRef]

55. Zheng, J.; Zhuang, Y.; Mao, H.Z.; Jang, I.C. Overexpression of SrDXS1 and SrKAH enhances steviol glycosides content in transgenic Stevia plants. BMC Plant Biol. 2019, 19, 1-16. [CrossRef]

56. Hidalgo, D.; Martínez-Márquez, A.; Cusidó, R.; Bru-Martínez, R.; Palazón, J.; Corchete, P. Silybum marianum cell cultures stably transformed with Vitis vinifera stilbene synthase accumulate t-resveratrol in the extracellular medium after elicitation with methyl jasmonate or methylated $\beta$-cyclodextrins. Eng. Life Sci. 2017, 17, 686-694. [CrossRef]

57. Dong, Y.; Duan, W.; He, H.; Su, P.; Zhang, M.; Song, G.; Fu, C.; Yu, L. Enhancing taxane biosynthesis in cell suspension culture of Taxus chinensis by overexpressing the neutral/alkaline invertase gene. Process Biochem. 2015, 50, 651-660. [CrossRef]

58. Mehrotra, S.; Srivastava, V.; Rahman, L.U.; Kukreja, A.K. Hairy root biotechnology-Indicative timeline to understand missing links and future outlook. Protoplasma 2015, 252, 1189-1201. [CrossRef] [PubMed]

59. Nigutová, K.; Kusari, S.; Sezgin, S.; Petijová, L.; Henzelyová, J.; Bálintová, M.; Spiteller, M.; Čellárová, E. Chemometric evaluation of hypericin and related phytochemicals in 17 in vitro cultured Hypericum species, hairy root cultures and hairy root-derived transgenic plants. J. Pharm. Pharmacol. 2019, 71, 46-57. [CrossRef] [PubMed]

60. Mottaki, Z.; Rezayian, M.; Niknam, V.; Ebrahimzadeh, H.; Mirmasoumi, M. Using hairy roots for production of secondary metabolites in Artemisia. Plant Biotechnol. Rep. 2019, 13, 263-271. [CrossRef]

61. Matvieieva, N.; Drobot, K.; Duplij, V.; Ratushniak, Y.; Shakhovsky, A.; Kyrpa-Nesmiian, T.; Mickevičius, S.; Brindza, J. Flavonoid content and antioxidant activity of Artemisia vulgaris L. "hairy" roots. Prep. Biochem. Biotechnol. 2019, 49, 82-87. [CrossRef]

62. Guo, Z.; Tan, H.; Lv, Z.; Ji, Q.; Huang, Y.; Liu, J.; Chen, D.; Diao, Y.; Si, J.; Zhang, L. Targeted expression of Vitreoscilla hemoglobin improves the production of tropane alkaloids in Hyoscyamus niger hairy roots. Sci. Rep. 2018, 8, 1-12.

63. Yin, Y.; Zhang, X.; Gao, Z.; Hu, T.; Yang, L.; Zhang, Z.; Li, W.; Liu, Y. Over-expressing root-specific $\beta$-amyrin synthase gene increases glycyrrhizic acid content in hairy roots of glycyrrhiza uralensis. Chin. Herb. Med. 2019, 11, 192-199. [CrossRef]

64. Bray, F.; Ferlay, J.; Soerjomataram, I.; Siegel, R.L.; Torre, L.A.; Jemal, A. Global cancer statistics 2018: GLOBOCAN estimates of incidence and mortality worldwide for 36 cancers in 185 countries. CA A Cancer J. Clin. 2018, 68, 394-424. [CrossRef]

65. George, V.C.; Dellaire, G.; Rupasinghe, H.P.V. Plant flavonoids in cancer chemoprevention: Role in genome stability. J. Nutr. Biochem. 2017, 45, 1-14. [CrossRef]

66. Bishayee, A.; Sethi, G. Bioactive natural products in cancer prevention and therapy: Progress and promise. Semin. Cancer Biol. 2016, 40-41, 1-3. [CrossRef] [PubMed] 
67. Chikara, S.; Nagaprashantha, L.D.; Singhal, J.; Horne, D.; Awasthi, S.; Singhal, S.S. Oxidative stress and dietary phytochemicals: Role in cancer chemoprevention and treatment. Cancer Lett. 2018, 413, 122-134. [CrossRef] [PubMed]

68. Seca, A.M.L.; Pinto, D.C.G.A. Plant secondary metabolites as anticancer agents: Successes in clinical trials and therapeutic application. Int. J. Mol. Sci. 2018, 19, 263. [CrossRef] [PubMed]

69. Wani, M.C.; Taylor, H.L.; Wall, M.E.; Coggon, P.; Mcphail, A.T. Plant Antitumor Agents.VI.The Isolation and Structure of Taxol, a Novel Antileukemic and Antitumor Agent from Taxus brevifolia. J. Am. Chem. Soc. 1971, 93, 2325-2327. [CrossRef]

70. Stage, T.B.; Bergmann, T.K.; Kroetz, D.L. Clinical Pharmacokinetics of Paclitaxel Monotherapy: An Updated Literature Review. Clin. Pharmacokinet. 2018, 57, 7-19. [CrossRef]

71. Fukaya, K.; Tanaka, Y.; Sato, A.C.; Kodama, K.; Yamazaki, H.; Ishimoto, T.; Nozaki, Y.; Iwaki, Y.M.; Yuki, Y.; Umei, K.; et al. Synthesis of paclitaxel. 1. synthesis of the abc ring of paclitaxel by SmI2-mediated cyclization. Org. Lett. 2015, 17, 2570-2573. [CrossRef]

72. Ho, C.; Chang, S.; Lung, J. The Strategies to Increase Taxol Production by Using Taxus mairei Cells Transformed with TS and DBAT Genes. Int. J. 2005, 3, 179-185.

73. Sykłowska-Baranek, K.; Pilarek, M.; Bonfill, M.; Kafel, K.; Pietrosiuk, A. Perfluorodecalin-supported system enhances taxane production in hairy root cultures of Taxus x media var. Hicksii carrying a taxadiene synthase transgene. Plant Cell Tissue Organ Cult. 2015, 120, 1051-1059. [CrossRef]

74. Hasan, M.M.; Kim, H.S.; Jeon, J.H.; Kim, S.H.; Moon, B.K.; Song, J.Y.; Shim, S.H.; Baek, K.H. Metabolic engineering of Nicotiana benthamiana for the increased production of taxadiene. Plant Cell Rep. 2014, 33, 895-904. [CrossRef]

75. Sykłowska-Baranek, K.; Grech-Baran, M.; Naliwajski, M.R.; Bonfill, M.; Pietrosiuk, A. Paclitaxel production and PAL activity in hairy root cultures of Taxus x media var. Hicksii carrying a taxadiene synthase transgene elicited with nitric oxide and methyl jasmonate. Acta Physiol. Plant. 2015, 37, 1-9. [CrossRef]

76. Martino, E.; Della Volpe, S.; Terribile, E.; Benetti, E.; Sakaj, M.; Centamore, A.; Sala, A.; Collina, S. The long story of camptothecin: From traditional medicine to drugs. Bioorg. Med. Chem. Lett. 2017, 27, 701-707. [CrossRef] [PubMed]

77. Sakato, K.; Tanaka, H.; Mukai, N.; Misawa, M. Isolation and Identification of Camptothecin from Cells of Camptotheca acuminata Suspension Cultures. Agric. Biol. Chem. 1974, 38, 217-218. [CrossRef]

78. Ni, X.; Wen, S.; Wang, X.; Wang, W.; Xu, H.; Kai, G. Enhancement of camptothecin production in Camptotheca acuminata hairy roots by overexpressing ORCA3 gene. J. Appl. Pharm. Sci. 2011, 1, 85-88.

79. Yan Pi Effects of over-expression of allene oxide cyclase on camptothecin production by cell cultures of Camptotheca acuminata. Afr. J. Biotechnol. 2012, 11, 6535-6541.

80. Cui, L.; Ni, X.; Ji, Q.; Teng, X.; Yang, Y.; Wu, C.; Zekria, D.; Zhang, D.; Kai, G. Co-overexpression of geraniol-10-hydroxylase and strictosidine synthase improves anti-cancer drug camptothecin accumulation in Ophiorrhiza pumila. Sci. Rep. 2015, 5, 1-9. [CrossRef] [PubMed]

81. Wetterauer, B.; Wildi, E.; Wink, M. Production of the anticancer compound camptothecin in root and hairy root cultures of Ophiorrhiza mungos L. In Biotechnological Approaches for Medicinal and Aromatic Plants—Conservation, Genetic Improvement and Utilization; Nitish, K., Ed.; Springer: Singapore, 2018; pp. S303-S341.

82. Wang, C.; Wu, C.; Wang, Y.; Xie, C.; Shi, M.; Nile, S.; Zhou, Z.; Kai, G. Transcription factor OpWRKY3 is involved in the development and biosynthesis of camptothecin and its precursors in Ophiorrhiza pumila hairy roots. Int. J. Mol. Sci. 2019, 20, 3996. [CrossRef]

83. Gutierrez-Camino, Á.; Umerez, M.; Martin-Guerrero, I.; García de Andoin, N.; Santos, B.; Sastre, A.; Echebarria-Barona, A.; Astigarraga, I.; Navajas, A.; Garcia-Orad, A. Mir-pharmacogenetics of Vincristine and peripheral neurotoxicity in childhood B-cell acute lymphoblastic leukemia. Pharm. J. 2018, 18, 704-712. [CrossRef]

84. Setty, B.A.; Stanek, J.R.; Mascarenhas, L.; Miller, A.; Bagatell, R.; Okcu, F.; Nicholls, L.; Lysecki, D.; Gupta, A.A. VIncristine, irinotecan, and temozolomide in children and adolescents with relapsed rhabdomyosarcoma. Pediatr. Blood Cancer 2018, 65, e26728. [CrossRef]

85. Büyükkapu Bay, S.; Kebudi, R.; Görgün, O.; Zülfikar, B.; Darendeliler, E.; Çakır, F.B. Vincristine, irinotecan, and temozolomide treatment for refractory/relapsed pediatric solid tumors: A single center experience. J. Oncol. Pharm. Pract. 2019, 25, 1343-1348. [CrossRef] 
86. Schönning, A.; Karlén, J.; Frisk, T.; Heyman, M.; Svahn, J.E.; Øra, I.; Kawan, L.; Holmqvist, B.M.; Björklund, C.; Harila-Saari, A.; et al. Venous thrombosis in children and adolescents with Hodgkin lymphoma in Sweden. Thromb. Res. 2017, 152, 64-68. [CrossRef]

87. Batra, S.; Wistinghausen, B. Pediatric Cancer: Solid Tumors and Lymphoma. In Mount Sinai Expert Guides; John Wiley \& Sons, Inc.: Hoboken, NJ, USA, 2019; pp. 543-555.

88. Schiller, G.J.; Damon, L.E.; Coutre, S.E.; Hsu, P.; Bhat, G.; Douer, D. High-dose vincristine sulfate liposome injection, for advanced, relapsed, or refractory philadelphia chromosome-negative acute lymphoblastic leukemia in an adolescent and young adult subgroup of a phase 2 clinical trial. J. Adolesc. Young Adult Oncol. 2018, 7, 546-552. [CrossRef] [PubMed]

89. Tomioka, K.; Nishikawa, J.; Moriwaki, J.; Sato, T. Effects of over-expression of strictosidine synthase and tryptophan decarboxylase on alkaloid production by cell cultures of Catharanthus roseus. J. Gen. Plant Pathol. 2013, 79, 414-419.

90. Sazegari, S.; Niazi, A.; Shahriari-Ahmadi, F.; Moshtaghi, N.; Ghasemi, Y. CrMYC1 transcription factor overexpression promotes the production of low abundance terpenoid indole alkaloids in Catharanthus roseus. Plant OMICS 2018, 11, 30-36. [CrossRef]

91. Pan, Q.; Wang, C.; Xiong, Z.; Wang, H.; Fu, X.; Shen, Q.; Peng, B.; Ma, Y.; Sun, X.; Tang, K. CrERF5, an AP2/ERF transcription factor, positively regulates the biosynthesis of bisindole alkaloids and their precursors in Catharanthus roseus. Front. Plant Sci. 2019, 10,1-13. [CrossRef]

92. Othman, L.; Sleiman, A.; Abdel-Massih, R.M. Antimicrobial activity of polyphenols and alkaloids in middle eastern plants. Front. Microbiol. 2019, 10, 911. [CrossRef]

93. Lelario, F.; Scrano, L.; de Franchi, S.; Bonomo, M.G.; Salzano, G.; Milan, S.; Milella, L.; Bufo, S.A. Identification and antimicrobial activity of most representative secondary metabolites from different plant species. Chem. Biol. Technol. Agric. 2018, 5, 1-12. [CrossRef]

94. Radulovic, N.S.; Blagojevic, P.D.; Stojanovic-Radic, Z.Z.; Stojanovic, N.M. Antimicrobial Plant Metabolites: Structural Diversity and Mechanism of Action. Curr. Med. Chem. 2013, 20, 932-952.

95. Khameneh, B.; Iranshahy, M.; Soheili, V.; Fazly Bazzaz, B.S. Review on plant antimicrobials: A mechanistic viewpoint. Antimicrob. Resist. Infect. Control 2019, 8, 118. [CrossRef]

96. Çetinkaya, R.A.; Yenilmez, E.; Petrone, P.; Yılmaz, S.; Bektöre, B.; Şimsek, B.; Kula Atik, T.; Özyurt, M.; Ünlü, A. Platelet-rich plasma as an additional therapeutic option for infected wounds with multi-drug resistant bacteria: In vitro antibacterial activity study. Eur. J. Trauma Emerg. Surg. 2019, 45, 555-565. [CrossRef]

97. Mahmoud, M.; Askora, A.; Barakat, A.B.; Rabie, O.E.F.; Hassan, S.E. Isolation and characterization of polyvalent bacteriophages infecting multi drug resistant Salmonella serovars isolated from broilers in Egypt. Int. J. Food Microbiol. 2018, 266, 8-13. [CrossRef]

98. Ghimire, B.K.; Seong, E.S.; Yu, C.Y.; Kim, S.H.; Chung, I.M. Evaluation of phenolic compounds and antimicrobial activities in transgenic Codonopsis lanceolata plants via overexpression of the $\gamma$-tocopherol methyltransferase ( $\gamma$-tmt) gene. S. Afr. J. Bot. 2017, 109, 25-33. [CrossRef]

99. Ghimire, B.K.; Yu, C.Y.; Chung, I.M. Assessment of the phenolic profile, antimicrobial activity and oxidative stability of transgenic Perilla frutescens L.overexpressing tocopherol methyltransferase ( $\gamma$-tmt) gene. Plant Physiol. Biochem. 2017, 118, 77-87. [CrossRef] [PubMed]

100. Sitarek, P.; Kowalczyk, T.; Rijo, P.; Białas, A.J.; Wielanek, M.; Wysokińska, H.; Garcia, C.; Toma, M.; Śliwiński, T.; Skała, E. Over-Expression of AtPAP1 Transcriptional Factor Enhances Phenolic Acid Production in Transgenic Roots of Leonurus sibiricus L. and Their Biological Activities. Mol. Biotechnol. 2018, 60, 74-82. [CrossRef] [PubMed]

101. Sitarek, P.; Kowalczyk, T.; Santangelo, S.; Białas, A.J.; Toma, M.; Wieczfinska, J.; Śliwiński, T.; Skała, E. The Extract of Leonurus sibiricus Transgenic Roots with AtPAP1 Transcriptional Factor Induces Apoptosis via DNA Damage and Down Regulation of Selected Epigenetic Factors in Human Cancer Cells. Neurochem. Res. 2018, 43, 1363-1370. [CrossRef]

102. Sitarek, P.; Kowalczyk, T.; Picot, L.; Michalska-Hejduk, D.; Bijak, M.; Białas, A.J.; Wielanek, M.; Śliwiński, T.; Skała, E. Growth of Leonurus sibiricus L. roots with over-expression of AtPAP1 transcriptional factor in closed bioreactor, production of bioactive phenolic compounds and evaluation of their biological activity. Ind. Crops Prod. 2018, 122, 732-739. [CrossRef] 
103. Sitarek, P.; Synowiec, E.; Kowalczyk, T.; Śliwiński, T.; Skała, E. An in vitro estimation of the cytotoxicity and genotoxicity of root extract from Leonurus sibiricus L. overexpressing AtPAP1 against different cancer cell lines. Molecules 2018, 23, 2049. [CrossRef]

104. Zalesińska, M.D.; Drag, M.; Poręba, M.; Borska, S.; Kulbacka, J. Anticancer properties of ester derivatives of betulin in human metastatic melanoma cells (Me-45). Cancer Cell Int. 2017, 17, 1-7.

105. Suzuki, H.; Fukushima, E.O.; Shimizu, Y.; Seki, H.; Fujisawa, Y.; Ishimoto, M.; Osakabe, K.; Osakabe, Y.; Muranaka, T. Lotus japonicus Triterpenoid Profile and Characterization of the CYP716A51 and LjCYP93E1 Genes Involved in Their Biosynthesis in Planta. Plant Cell Physiol. 2019, 60, 2496-2509. [CrossRef]

106. Xia, K.; Liu, X.; Zhang, Q.; Qiang, W.; Guo, J.; Lan, X.; Chen, M.; Liao, Z. Promoting scopolamine biosynthesis in transgenic Atropa belladonna plants with $\mathrm{pmt}$ and $h 6 \mathrm{~h}$ overexpression under field conditions. Plant Physiol. Biochem. 2016, 106, 46-53. [CrossRef]

107. Sohrabi, S.M.; Ismaili, A.; Nazarian-Firouzabadi, F. Simultaneous over-expression and silencing of some benzylisoquinoline alkaloid biosynthetic genes in opium poppy. Ind. Crops Prod. 2018, 123, 581-590. [CrossRef]

108. Li, Q.; Yu, H.M.; Meng, X.F.; Lin, J.S.; Li, Y.J.; Hou, B.K. Ectopic expression of glycosyltransferase UGT76E11 increases flavonoid accumulation and enhances abiotic stress tolerance in Arabidopsis. Plant Biol. 2018, 20, 10-19. [CrossRef]

109. Lee, W.J.; Kim, J.; Lee, D.; Hong, S.W.; Lee, H. Arabidopsis UDP-glycosyltransferase 78D1-overexpressing plants accumulate higher levels of kaempferol 3-O- $\beta$-d-glucopyranoside than wild-type plants. Appl. Biol. Chem. 2017, 60, 647-652. [CrossRef]

110. Wang, F.; Kong, W.; Wong, G.; Fu, L.; Peng, R.; Li, Z.; Yao, Q. AtMYB12 regulates flavonoids accumulation and abiotic stress tolerance in transgenic Arabidopsis thaliana. Mol. Gen. Genom. 2016, 291, 1545-1559. [CrossRef]

111. Wang, F.; Ren, G.; Li, F.; Qi, S.; Xu, Y.; Wang, B.; Yang, Y.; Ye, Y.; Zhou, Q.; Chen, X. A chalcone synthase gene AeCHS from Abelmoschus esculentus regulates flavonoid accumulation and abiotic stress tolerance in transgenic Arabidopsis. Acta Physiol. Plant. 2018, 40, 1-13. [CrossRef]

112. Wang, F.; Zhu, H.; Kong, W.; Peng, R.; Liu, Q.; Yao, Q. The Antirrhinum AmDEL gene enhances flavonoids accumulation and salt and drought tolerance in transgenic Arabidopsis. Planta 2016, 244, 59-73. [CrossRef]

113. Park, S.C.; Kim, Y.H.; Kim, S.H.; Jeong, Y.J.; Kim, C.Y.; Lee, J.S.; Bae, J.Y.; Ahn, M.J.; Jeong, J.C.; Lee, H.S.; et al. Overexpression of the IbMYB1 gene in an orange-fleshed sweet potato cultivar produces a dual-pigmented transgenic sweet potato with improved antioxidant activity. Physiol. Plant. 2015, 153, 525-537. [CrossRef]

114. Park, S.C.; Kim, S.H.; Park, S.; Lee, H.U.; Lee, J.S.; Park, W.S.; Ahn, M.J.; Kim, Y.H.; Jeong, J.C.; Lee, H.S.; et al. Enhanced accumulation of carotenoids in sweetpotato plants overexpressing IbOr-Ins gene in purple-fleshed sweetpotato cultivar. Plant Physiol. Biochem. 2015, 86, 82-90. [CrossRef]

115. Mierziak, J.; Wojtasik, W.; Kostyn, K.; Czuj, T.; Szopa, J.; Kulma, A. Crossbreeding of transgenic flax plants overproducing flavonoids and glucosyltransferase results in progeny with improved antifungal and antioxidative properties. Mol. Breed. 2014, 34, 1917-1932. [CrossRef]

116. Huang, W.; Khaldun, A.B.M.; Chen, J.; Zhang, C.; Lv, H.; Yuan, L.; Wang, Y. A R2R3-MYB transcription factor regulates the flavonol biosynthetic pathway in a traditional Chinese medicinal plant, Epimedium sagittatum. Front. Plant Sci. 2016, 7, 1-12. [CrossRef]

117. Jeong, Y.J.; An, C.H.; Woo, S.G.; Park, J.H.; Lee, K.W.; Lee, S.H.; Rim, Y.; Jeong, H.J.; Ryu, Y.B.; Kim, C.Y. Enhanced production of resveratrol derivatives in tobacco plants by improving the metabolic flux of intermediates in the phenylpropanoid pathway. Plant Mol. Biol. 2016, 92, 117-129. [CrossRef]

118. Shi, J.; Li, W.; Gao, Y.; Wang, B.; Li, Y.; Song, Z. Enhanced rutin accumulation in tobacco leaves by overexpressing the NtFLS2 gene. Biosci. Biotechnol. Biochem. 2017, 81, 1721-1725. [CrossRef]

119. Yuan, Y.; Qi, L.; Yang, J.; Wu, C.; Liu, Y.; Huang, L. A Scutellaria baicalensis R2R3-MYB gene, SbMYB8, regulates flavonoid biosynthesis and improves drought stress tolerance in transgenic tobacco. Plant Cell Tissue Organ Cult. 2015, 120, 961-972. [CrossRef]

120. Gwak, Y.S.; Han, J.Y.; Adhikari, P.B.; Ahn, C.H.; Choi, Y.E. Heterologous production of a ginsenoside saponin (compound $\mathrm{K}$ ) and its precursors in transgenic tobacco impairs the vegetative and reproductive growth. Planta 2017, 245, 1105-1119. [CrossRef]

121. Liu, Y.; Wang, L.; Zhang, J.; Yu, B.; Wang, J.; Wang, D. The MYB transcription factor StMYBA1 from potato requires light to activate anthocyanin biosynthesis in transgenic tobacco. J. Plant Biol. 2017, 60, 93-101. [CrossRef] 
122. Sun, W.; Meng, X.; Liang, L.; Li, Y.; Zhou, T.; Cai, X.; Wang, L.; Gao, X. Overexpression of a Freesia hybrida flavonoid 3-O-glycosyltransferase gene, Fh3GT1, enhances transcription of key anthocyanin genes and accumulation of anthocyanin and flavonol in transgenic petunia (Petunia hybrida). Vitro Cell. Dev. Biol. Plant 2017, 53, 478-488. [CrossRef]

123. Ai, T.N.; Naing, A.H.; Yun, B.W.; Lim, S.H.; Kim, C.K. Overexpression of rsmyb1 enhances anthocyanin accumulation and heavy metal stress tolerance in transgenic petunia. Front. Plant Sci. 2018, 9, 1-15. [CrossRef]

124. Li, H.; Liu, J.; Pei, T.; Bai, Z.; Han, R.; Liang, Z. Overexpression of SmANS enhances anthocyanin accumulation and alters phenolic acids content in Salvia miltiorrhiza and Salvia miltiorrhiza bge f. Alba plantlets. Int. J. Mol. Sci. 2019, 20, 2225. [CrossRef]

125. Liu, Y.; Sun, G.; Zhong, Z.; Ji, L.; Zhang, Y.; Zhou, J.; Zheng, X.; Deng, K. Overexpression of AtEDT1 promotes root elongation and affects medicinal secondary metabolite biosynthesis in roots of transgenic Salvia miltiorrhiza. Protoplasma 2017, 254, 1617-1625. [CrossRef]

126. Yang, N.; Zhou, W.; Su, J.; Wang, X.; Li, L.; Wang, L.; Cao, X.; Wang, Z. Overexpression of smMYC2 increases the production of phenolic acids in Salvia miltiorrhiza. Front. Plant Sci. 2017, 8, 1-12. [CrossRef]

127. Wang, B.; Niu, J.; Li, B.; Huang, Y.; Han, L.; Liu, Y.; Zhou, W.; Hu, S.; Li, L.; Wang, D.; et al. Molecular characterization and overexpression of SmJMT increases the production of phenolic acids in Salvia miltiorrhiza. Int. J. Mol. Sci. 2018, 19, 3788. [CrossRef]

128. Lim, W.; Li, J. Co-expression of onion chalcone isomerase in Del/Ros1-expressing tomato enhances anthocyanin and flavonol production. Plant Cell Tissue Organ Cult. 2017, 128, 113-124. [CrossRef]

129. Jian, W.; Cao, H.; Yuan, S.; Liu, Y.; Lu, J.; Lu, W.; Li, N.; Wang, J.; Zou, J.; Tang, N.; et al. SIMYB75, an MYB-type transcription factor, promotes anthocyanin accumulation and enhances volatile aroma production in tomato fruits. Hortic. Res. 2019, 6, 22. [CrossRef]

130. Kaushik, P. Standardisation of an Agroinfiltration Protocol for Eggplant Fruits and Proving its Usefulness by Over-expressing the SmHQT Gene. Preprints 2019. [CrossRef]

131. Qiu, J.; Sun, S.; Luo, S.; Zhang, J.; Xiao, X.; Zhang, L.; Wang, F.; Liu, S. Arabidopsis AtPAP1 transcription factor induces anthocyanin production in transgenic Taraxacum brevicorniculatum. Plant Cell Rep. 2014, 33, 669-680. [CrossRef]

132. Nomani, M.; Sadat Noori, S.A.; Tohidfar, M.; Ramshini, H. Overexpression of TPS2 gene to increase thymol content using Agrobacterium tumefaciens-mediated transformation in Trachyspermum ammi (Qom ecotype). Ind. Crops Prod. 2019, 130, 63-70. [CrossRef]

133. Pandey, V.; Srivastava, R.; Akhtar, N.; Mishra, J.; Mishra, P.; Verma, P.C. Expression of Withania somnifera Steroidal Glucosyltransferase gene Enhances Withanolide Content in Hairy Roots. Plant Mol. Biol. Rep. 2016, 34, 681-689. [CrossRef]

134. Yuan, Y.; Liu, W.; Zhang, Q.; Xiang, L.; Liu, X.; Chen, M.; Lin, Z.; Wang, Q.; Liao, Z. Overexpression of artemisinic aldehyde $\Delta 11$ (13) reductase gene-enhanced artemisinin and its relative metabolite biosynthesis in transgenic Artemisia annua L. Biotechnol. Appl. Biochem. 2015, 62, 17-23. [CrossRef]

135. Inthima, P.; Nakano, M.; Otani, M.; Niki, T.; Nishijima, T.; Koshioka, M.; Supaibulwatana, K. Overexpression of the gibberellin 20-oxidase gene from Torenia fournieri resulted in modified trichome formation and terpenoid metabolities of Artemisia annua. Plant Cell Tissue Organ Cult. 2017, 129, 223-236. [CrossRef]

136. Fan, G.; Nie, T.; Huang, Y.; Zhan, Y. GSNOR deficiency enhances betulin production in Betula platyphylla. Trees Struct. Funct. 2018, 32, 847-853. [CrossRef]

137. Lu, S.; Zhang, Y.; Zhu, K.; Yang, W.; Ye, J.; Chai, L.; Xu, Q.; Deng, X. The citrus transcription factor CsMADS6 modulates carotenoid metabolism by directly regulating carotenogenic genes. Plant Physiol. 2018, 176, 2657-2676. [CrossRef]

138. Mendoza-Poudereux, I.; Muñoz-Bertomeu, J.; Navarro, A.; Arrillaga, I.; Segura, J. Enhanced levels of S-linalool by metabolic engineering of the terpenoid pathway in spike lavender leaves. Metab. Eng. 2014, 23, 136-144. [CrossRef] [PubMed]

139. Wang, Q.; Reddy, V.A.; Panicker, D.; Mao, H.Z.; Kumar, N.; Rajan, C.; Venkatesh, P.N.; Chua, N.H.; Sarojam, R. Metabolic engineering of terpene biosynthesis in plants using a trichome-specific transcription factor MsYABBY5 from spearmint (Mentha spicata). Plant Biotechnol. J. 2016, 14, 1619-1632. [CrossRef] [PubMed] 
140. Kang, Y.M.; Park, D.J.; Lee, D.G.; Song, H.J.; Kang, S.M.; Min, J.Y.; Moon, B.C.; Lee, C.K.; Jeon, K.S.; Shivappakarigar, C.; et al. Over expression of IPP isomerase and limonene synthase enzymes in Mentha spicata and their influence on the terpenoid metabolism. Rom. Biotechnol. Lett. 2015, 20,10358-10368.

141. Hamachi, A.; Nisihara, M.; Saito, S.; Rim, H.; Takahashi, H.; Islam, M.; Uemura, T.; Ohnishi, T.; Ozawa, R.; Maffei, M.E.; et al. Overexpression of geraniol synthase induces heat stress susceptibility in Nicotiana tabacum. Planta 2019, 249, 235-249. [CrossRef] [PubMed]

142. Rahimi, S.; Kim, Y.J.; Sukweenadhi, J.; Zhang, D.; Yang, D.C. PgLOX6 encoding a lipoxygenase contributes to jasmonic acid biosynthesis and ginsenoside production in Panax ginseng. J. Exp. Bot. 2016, 67, 6007-6019. [CrossRef] [PubMed]

143. Jadaun, J.S.; Sangwan, N.S.; Narnoliya, L.K.; Singh, N.; Bansal, S.; Mishra, B.; Sangwan, R.S. Over-expression of DXS gene enhances terpenoidal secondary metabolite accumulation in rose-scented geranium and Withania somnifera: Active involvement of plastid isoprenogenic pathway in their biosynthesis. Physiol. Plant. 2017, 159, 381-400. [CrossRef]

144. Wei, T.; Gao, Y.; Deng, K.; Zhang, L.; Yang, M.; Liu, X.; Qi, C.; Wang, C.; Song, W.; Zhang, Y.; et al. Enhancement of tanshinone production in Salvia miltiorrhiza hairy root cultures by metabolic engineering. Plant Methods 2019, 15, 1-11. [CrossRef]

145. Deng, C.; Hao, X.; Shi, M.; Fu, R.; Wang, Y.; Zhang, Y.; Zhou, W.; Feng, Y.; Makunga, N.P.; Kai, G. Tanshinone production could be increased by the expression of SmWRKY2 in Salvia miltiorrhiza hairy roots. Plant Sci. 2019, 284, 1-8. [CrossRef]

146. Vaccaro, M.; Malafronte, N.; Alfieri, M.; de Tommasi, N.; Leone, A. Enhanced biosynthesis of bioactive abietane diterpenes by overexpressing AtDXS or AtDXR genes in Salvia sclarea hairy roots. Plant Cell Tissue Organ Cult. 2014, 119, 65-77. [CrossRef]

147. Tian, N.; Liu, F.; Wang, P.; Yan, X.; Gao, H.; Zeng, X.; Wu, G. Overexpression of BraLTP2, a lipid transfer protein of Brassica napus, results in increased trichome density and altered concentration of secondary metabolites. Int. J. Mol. Sci. 2018, 19, 1733. [CrossRef]

148. Chahel, A.A.; Zeng, S.; Yousaf, Z.; Liao, Y.; Yang, Z.; Wei, X.; Ying, W. Plant-specific transcription factor LrTCP4 enhances secondary metabolite biosynthesis in Lycium ruthenicum hairy roots. Plant Cell Tissue Organ Cult. 2019, 136, 323-337. [CrossRef]

149. Yamazaki, M.; Rai, A.; Yoshimoto, N.; Saito, K. Perspective: Functional genomics towards new biotechnology in medicinal plants. Plant Biotechnol. Rep. 2018, 12, 69-75. [CrossRef] 